\title{
UPAYA PENINGKATAN PEMBELAJARAN LOMPAT JAUH GAYA MENGGANTUNG DENGAN METODE BAGIAN PROGRESIF SISWA SMAN 1 CEPER
}

\section{IMPROVING THE LEARNING OF HANG STYLE LONG JUMP WITH PROGRESSIVE PART METHOD OF STUDENTS AT SMAN 1 CEPER}

\author{
Mufti Hidayat, Tomoliyus \\ SMAN 1 Ceper, Universitas Negeri Yogyakarta \\ mufti_taekwondo@yahoo.co.id, tomoliyus@yahoo.co.id
}

\begin{abstract}
Abstrak
Penelitian ini bertujuan untuk meningkatkan pembelajaran teknik lompat jauh gaya menggantung siswa kelas X F SMAN 1 Ceper dengan metode bagian progresif. Jenis penelitian ini adalah penelitian tindakan kelas. Penelitian tindakan adalah kajian sistematik dari upaya perbaikan pelaksanaan praktik pendidikan oleh sekelompok guru dengan melakukan tindakan-tindakan dalam pembelajaran, berdasarkan refleksi mengenai hasil dari tindakan-tindakan tersebut. Penelitian ini dilaksanakan di SMAN 1 Ceper Klaten semester genap tahun pelajaran 2011/2012. Subjek penelitian adalah kelas X F dengan jumlah siswa 23 anak. Penelitian ini dilaksanakan pada bulan Maret-Mei 2012 . Hasil analisis penilaian terhadap siswa-siswa kelas X F SMAN 1 Ceper pada cabang atletik lompat jauh gaya menggantung pada semester gasal tahun pelajaran 2011/2012, bahwa mayoritas siswa mengalami kesulitan melakukan tolakan. Hasil penelitian menunjukkan belum terjadi peningkatan hasil belajar siswa ratarata skor pada siklus I adalah 68,75 . Pada siklus II terjadi peningkatan hasil belajar siswa rata-rata skor adalah 80,97 .
\end{abstract}

Kata kunci : Lompat Jauh Gaya Menggantung, Metode Bagian Progresif

\begin{abstract}
This research is aimed to improve the implementation of hang style long jump technique with progressive part method of class XF students at SMAN 1 Ceper The type of the research is classroom action research. Classroom action research is a systematic study of improving the educational practice implementation by a group of teachers to perform actions in learning, based on their reflections on the results of the actions. This study was conducted at SMAN 1 Ceper Klaten which was in the even semester of 2011/2012 academic year and the research subject was class XF consisting of 23 students. The research was conducted from March to May 2012. Based on the assessment analysis result of class X students SMAN 1 Ceper' on athletic hang style long jump in the even semester of 2011/2012 academic year, the majority of the students have difficulty in doing repulsion. The research result shows that there is not yet an increase of the students' learning result, the average score in Cycle I is 68.75. In Cycle II there is an increase of the students' learning result, the average score is 80.97
\end{abstract}

Keywords: Hang Style Long Jump, Progressive Part Method 


\section{Pendahuluan}

Pendidikan jasmani olahraga dan kesehatan (Penjasorkes) merupakan bagian integral dari sistem pendidikan secara keseluruhan, yang memfokuskan pengembangan aspek kebugaran jasmani, keterampilan gerak, keterampilan berfikir kritis, stabilitas emosional, keterampilan sosial, penalaran dan tindakan moral melalui aktivitas jasmani. Peningkatan keterampilan gerak, kesegaran jasmani, pengetahuan, dan sikap positif terhadap Penjasorkes sangat ditentukan oleh sebuah kurikulum yang baik. Kurikulum terlalu abstrak untuk didefinisikan secara tegas dan jelas, sebab di dalam kurikulum tersebut termasuk segala sesuatu yang direncanakan dan diterapkan oleh para guru, baik secara implisit maupun eksplisit. Namun secara sederhana dapat dinyatakan bahwa kurikulum merupakan perencanaan dan program jangka panjang tentang berbagai pengalaman belajar, model, tujuan, materi, metode, sumber, dan evaluasi (Depdiknas, 2007, p.6).

Materi mata pelajaran Penjasorkes yang terdapat pada Kurikulum Tingkat Satuan Pendidikan (KTSP) meliputi: permainan, atletik, senam, renang (aktivitas air), olahraga tradisional, aktivitas pengembangan, dan aktivitas luar kelas. Lompat jauh gaya menggantung merupakan bagian dari cabang atletik nomor lompat jauh gaya menggantung berupa melompat di atas papan tolakan untuk menghasilkan lompatan yang jauh. Ada beberapa gaya yang terdapat dalam lompat jauh, yakni: (1) gaya jongkok (gaya tuck). (2) gaya berjalan di udara (walking in the air). (3) gaya menggantung (gaya hang) (Tim Bina Karya Guru, 2004, p.5).

Dalam pembelajaran lompat jauh gaya menggantung diharapkan siswa dapat menguasai dan memahami teknik lompat jauh gaya menggantung dengan baik. Teknik yang harus dikuasai antara lain awalan, tolakan, melayang dan mendarat. Hal ini dapat ditunjukkan dari hasil unjuk kerja siswa yang mencapai KKM (Kriteria Ketuntasan Minimal) yang ditentukan oleh sekolah atau Musyawarah Guru Mata Pelajaran (MGMP) Penjas Kabupaten Klaten. Siswa dapat mengambil makna yang ada dalam pembelajaran lompat jauh gaya menggantung, seperti disiplin, percaya diri, bertanggung jawab dan dapat dipraktikkan dalam kehidupan di masyarakat, sehingga terbentuk karakter yang baik di dalam diri siswa tersebut.

Namun dalam pembelajaran lompat jauh gaya menggantung siswa kurang berminat karena cenderung membosankan. Hal ini ditunjukkan dari siswa yang belum menguasai teknik lompat jauh gaya menggantung dengan baik, siswa tidak ada motivasi dalam melakukan terlihat dalam proses pembelajaran siswa. Hal di atas berakibat tidak tercapainya kriteria ketuntasan minimal untuk pembelajaran lompat jauh, ini merupakan masalah yang harus dipecahkan.

Ada beberapa masalah yang menjadi kendala pada saat pembelajaran atletik, khususnya pada saat lompat jauh gaya mengantung. Kendala yang dihadapi antara lain fasilitas yang kurang memadai, siswa kurang tertarik dengan atletik. lompat jauh gaya menggantung adalah olahraga yang menjemukan, komunikasi guru satu arah, dan hasil belajar lompat jauh gaya menggantung tidak mencapai KKM.

Apabila dilihat dari faktor fasilitas yaitu SMAN 1 Ceper Klaten tidak memiliki bak lompat yang memadai. Pasir yang digunakan terlalu kasar banyak terdapat kerikil kecil yang dapat menyebabkan telapak kaki terluka. Volume pasir tidak sesuai dengan besar bak lompat tersebut. Papan tumpu tidak ada, selama ini menggunakan keset sabut kelapa. Anak sering terpeleset karena papan tumpu tidak permanen sehingga tidak nyaman saat melakukan tolakan.

Selama proses pembelajaran jasmani siswa Kelas X F SMAN 1 Ceper Klaten dalam mengikuti olahraga atletik khususnya nomor lompat jauh gaya menggantung masih kurang berminat, karena pada umumnya siswa senang olahraga yang berkaitan dengan permainan yaitu permainan bola tangan (bola voli) dan bola kaki (sepak bola). Permainan bola dirasakan lebih menantang dan dapat bergerak secara aktif.

Olahraga atletik nomor lompat jauh gaya menggantung merupakan olahraga yang menjemukan bagi siswa kelas X F, sehingga cepat merasa bosan dalam mengikuti pembelajaran olahraga atletik nomor lompat jauh. Berdasarkan permasalahan di atas penulis lebih termotivasi dalam upaya peningkatan pembelajaran lompat jauh. Berdasarkan pengamatan penulis dari beberapa pembelajaran lompat jauh gaya menggantung siswa banyak melakukan kesalahan pada saat tolakan dan mendarat yang salah.

Dalam pembelajaran olahraga kepada siswa, apabila guru masih menggunakan paradigma pembelajaran lama dalam arti komunikasi dalam pembelajaran olahraga cenderung berlangsung satu arah, umumnya dari guru ke siswa, guru lebih mendominasi pembelajaran, maka pembelajaran cenderung monoton sehing- 
ga mengakibatkan siswa merasa jenuh. Oleh karena itu dalam mengajarkan olahraga kepada siswa, guru hendaknya lebih memilih berbagai variasi pendekatan, strategi, atau metode yang sesuai dengan situasi sehingga tujuan pembelajaran yang direncanakan akan tercapai.

Perlu diketahui bahwa baik atau tidaknya suatu pemilihan metode pembelajaran akan tergantung tujuan pembelajarannya, kesesuaian dengan materi pembelajaran, tingkat perkembangan siswa, kemampuan guru dalam mengelola pembelajaran serta mengoptimalkan sumbersumber belajar yang ada.

Di SMAN 1 Ceper Klaten proses pembelajaran guru hanya menggunakan metode drill untuk menyampaikan materi lompat jauh gaya menggantung. Dengan metode drill siswa kurang menguasai teknik lompat jauh gaya menggantung. Proses pembelajaran atletik khususnya nomor lompat, anak-anak kurang termotivasi sehingga merasa enggan mengikuti karena guru kurang memberikan motivasi dan semangat. Guru harus memberikan semangat kepada siswa agar pembelajaran aktif dan siswa mempunyai antusias terhadap pembelajaran lompat jauh.

Untuk mengevaluasi hasil belajar lompat jauh gaya menggantung selama ini guru menilai dari jarak lompatan siswa. Rencana Pelaksanaan Pembelajaran (RPP) telah dijelaskan bahwa kompetensi dasar menyebutkan dasar penilaian adalah anak-anak dapat mempraktik gerak dasar lompat jauh gaya menggantung, sehingga penilaian yang dilakukan dengan tepat dan sesuai teori yang diajarkan. Untuk memperbaiki cara penilaian perlu dibuat draf atau rubrik penilaian yang sesuai dengan indikator di dalam RPP.

Salah satu penyebab masalah-masalah tersebut di atas karena guru belum sesuai memilih metode untuk mengajarkan teknik lompat jauh gaya menggantung SMAN 1 Ceper Klaten siswa kelas X Tahun Ajaran 2011/2012. Metode yang digunakan dalam proses pembelajaran selalu terpusat pada kemampuan guru dalam memberikan materi, sehingga faktor kemampuan siswa tidak diperhatikan. Kemampuan setiap siswa perlu menggunakan metode yang tepat dalam penyampaian materi lompat jauh gaya mengggantung.

Berdasarkan masalah tersebut perlu dicari solusi, agar siswa dapat mencapai KKM. Dengan melakukan penelitian tindakan kelas yang berjudul "Upaya Peningkatan Pembelajaran Lompat Jauh Gaya Menggantung Dengan
Metode Bagian Progresif SMAN 1 Ceper Klaten siswa kelas X Tahun Ajaran 2011/2012". Dengan PTK yang akan dilaksanakan diharapkan mampu untuk mengatasi tentang masalah pembelajaran lompat jauh gaya menggantung.

Identifikasi Masalah

Berdasarkan latar belakang masalah tersebut dapat diidentifikasi permasalahan sebagai berikut: (1) Kurang berminatnya siswa dalam mengikuti pelajaran atletik pada lompat jauh; (2) Lompat jauh gaya menggantung merupakan olahraga yang menjemukan bagi siswa; (3) Komunikasi yang berpusat kepada guru; (4) Penilaian hasil belajar siswa kelas X F SMAN 1 Ceper Klaten untuk lompat jauh gaya menggantung tidak mencapai KKM.

Pembatasan Masalah

Mengingat permasalahan yang akan dibahas dalam penelitian ini sangat luas dan komplek, maka perlu pembatasn masalah. Adapun yang akan dikaji dalam penelitian ini adalah pembelajaran menggunakan metode bagian progresif dan teknik lompat jauh gaya menggantung pada siswa kelas X F SMAN 1 Ceper Klaten tahun ajaran 2011/2012.

\section{Rumusan Masalah}

Berdasarkan uraian latar belakang di atas, permasalahan penelitian dapat dirumuskan sebagai berikut: apakah pembelajaran penggunaan metode bagian progresif dapat meningkatkan teknik lompat jauh gaya menggantung siswa kelas X F SMAN 1 Ceper Klaten tahun ajaran 2011/2012?

Tujuan Penelitian

Sesuai dengan permasalahan di atas, maka tujuan penelitian ini adalah untuk meningkatkan pelaksanaan teknik lompat jauh gaya menggantung siswa kelas X F SMAN 1 Ceper Klaten tahun ajaran 2011/2012.

\section{Metode}

Jenis Penelitian

Sugiyanto (2007, p.12) yang menyatakan bahwa penelitian tindakan adalah kajian sistematik dari upaya perbaikan pelaksanaan praktik pendidikan oleh sekelompok guru dengan melakukan tindakan-tindakan dalam pembelajaran, berdasarkan refleksi mengenai hasil dari tindakan-tindakan tersebut.

Wiraatmadja (2005, p.4) penelitian tindakan kelas adalah proses yang mana guru 
mengkombinasikan praktik dan evaluasi secara bersamaan. Meningkatkan atas teori personal artikulasi sebuah pembagian nilai-nilai, mencoba strategi-strategi untuk memberi nilai-nilai yang diekspresikan pada praktek-praktek yang lebih konsisten. Dengan nilai-nilai pendidikan yang mendukung, merekam/mencatat pekerjaan dalam sebuah bentuk yang disediakan, agar dimengerti oleh guru yang lain, dan membangun teori yang baru. Dengan demikian penelitian tindakan kelas dalam penelitian ini adalah bentuk yang dilakukan oleh guru secara kolaborasi dalam proses pembelajaran guna memperbaiki keadaan ke arah yang lebih baik.

Penelitian ini diharapkan dapat mengungkap berbagai informasi kualitatif dengan analisis yang teliti dan penuh makna. Seorang guru yang profesional tidak akan membiarkan masalah yang dihadapinya terus berlanjut. Oleh karena itu guru perlu melakukan tindakan untuk memcahkan masalah yang dihadapinya agar proses pembelajaran berlangsung lancar, sehingga tujuan pembelajaran dapat dicapai secara efisien. Melalui pendekatan penelitian tindakan kelas ini permasalahan yang dirasakan dan ditemukan oleh guru dan siswa dapat dicari solusinya.

Desain Penelitian

Desain penelitian tindakan kelas yang dikembangkan dalam penelitian ini adalah desain yang dikemukakan oleh Kemmis dan Taggrat (1988, pp.11-14) yang menggambarkan bahwa penelitian tindakan kelas dilaksanakan melalui beberapa siklus, dan tiap siklus terdiri dari 4 tahap. Adapun tahap-tahap tersebut sebagai berikut: (a) perencanaan, (b) pelaksanaan, (c) observasi, (d) refleksi.

\section{Perencanaan}

Pada tahap perencanaan ini kegiatan yang dilakukan adalah menentukan fokus penelitian. Selanjutnya guru merencanakan dan mengevaluasi pelaksanaan pembelajaran yang telah berlangsung sebelumnya, mendata kelemahan-kelemahannya, diidentifikasi dan dianalisis kelayakan untuk diatasi dengan penelitian tindakan kelas.

\section{Pelaksanaan tindakan}

Dalam tahap ini untuk mengatasi masalah-masalah yang telah dipilih, peneliti melaksanakan pembelajaran dengan menggunakan strategi-strategi yang sesuai, dalam hal ini adalah menggunakan metode bagian progresif dalam belajar keterampilan lompat jauh gaya menggantung. Kolaborator mengamati dan membuat catatan-catatan mengenai jalannya pembelajaran.

\section{Observasi}

Kolaborator mengamati, mencatat, dan kemudian mendokumentasikan hal-hal yang terjadi selama tindakan berlangsung, dengan maksud untuk mengetahui kesesuaian antara pelaksanaan tindakan dengan rencana tindakan yang telah ditetapkan. Pengamatan yang dilakukan secara komprehensif dengan memanfaatkan pedoman dan catatan lapangan.

\section{Refleksi}

Dalam refleksi peneliti bersama kolaborator mendiskusikan hasil pengamatan yang dilakukan, kelemahan dan kekurangan yang telah ditemukan pada siklus terdahulu dapat digunakan sebagai dasar penyusunan rencana pada siklus berikutnya, sehingga siklus selanjutnya akan menjadi lebih baik dari siklus sebelumnya.

Langkah langkah penelitian tindakan secara keseluruhan berbentuk spiral. Seperti lingkaran pada spiral tersebut menggambarkan kegiatan yang utuh, yang dinamakan siklus, karena kalau hanya terdiri dari satu siklus belum berbentuk spiral. Maksudnya agar kekurangan pada siklus pertama dapat diperbaiki pada siklus-siklus berikutnya, sehingga terjadi peningkatan hasil belajar secara terus menerus. Pengertian siklus adalah suatu putaran kegiatan yang terdiri dari perencanaan, tindakan, observasi, dan refleksi. Siklus akan berulang sampai tercapai ukuran keberhasilan yang inginkan. Dalam penelitian tindakan kelas ini keberhasilan yang diinginkan adalah hasil proses belajar lompat jauh gaya menggantung meningkat di atas KKM yaitu: 75 . 


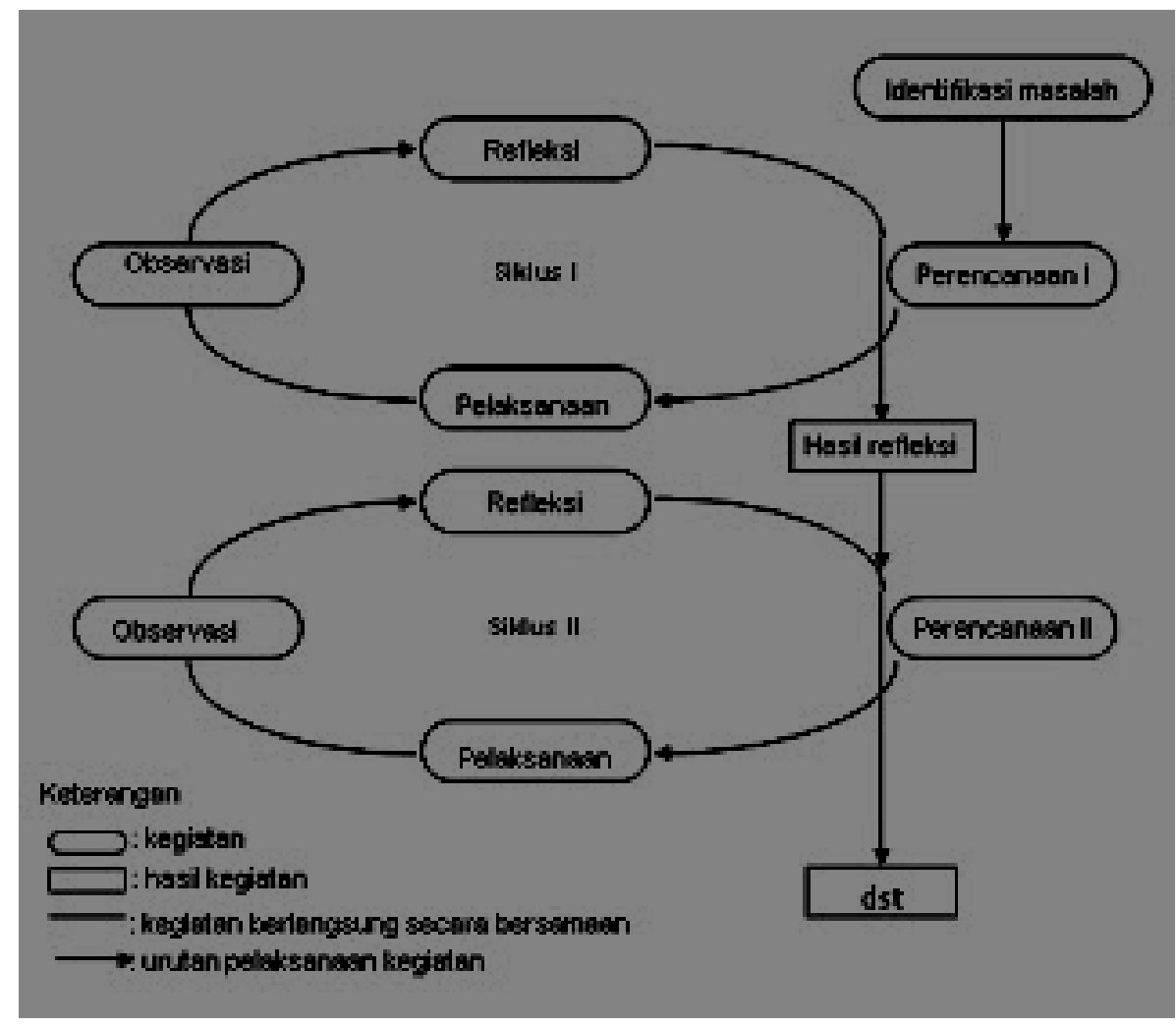

Gambar 1. Gambar Langkah PTK berbentuk spiral (Wiraatmadja 2005, p.4)

\section{Lokasi Penelitian}

Penelitian ini dilaksanakan di SMAN 1 Ceper Klaten semester genap tahun Pelajaran 2011/2012 yang berlokasi di Desa Kajen Kecamatan Ceper Kabupaten Klaten. Alasan pemilihan lokasi penelitian di sekolah ini dikarenakan peneliti sebagai guru di sekolah tersebut.

\section{Waktu Penelitian}

Penelitian ini akan dilaksanakan pada bulan Maret-Mei 2012, dengan harapan data yang diperoleh dirasa sudah lengkap sesuai yang diharapkan. Penelitian tindakan kelas ini sangat tergantung keaktifan siswa, guru serta kolaborator sehingga hasil yang diharapkan setiap siklus pembelajaran dapat tercapai dengan baik.

\section{Subjek Penelitian}

Subjek penelitian adalah kelas X F dengan jumlah siswa 23 anak. Dalam PTK ini ju- ga dilakukan wawancara terhadap guru, kepala sekolah dan siswa, di samping pengamatan di lapangan dengan maksud agar mendapatkan hasil yang sesuai harapan.

Prosedur Pengumpulan Data

Langkah-langkah persiapan setelah adanya masalah yang perlu dipecahkan melalui PTK ini adalah: (1) Melakukan studi awal dengan melakukan refleksi, yakni kegiatan diskusi dengan guru dengan permasalahan yang ditemukan; (2) Membuat rencana tindakan, meliputi: (a) membuat rencana pembelajaran, (b) membuat kesepakatan dengan kolaborator; (3) Siklus penelitian

Jumlah siklus dalam PTK ini tidak ditentukan sejak awal, tetapi sangat dipengaruhi oleh data yang diperoleh dan hasil analisisnya. Apabila data yang diperoleh sudah memuaskan untuk menjawab permasalahan penelitian, maka siklus penelitian dianggap selesai 


\section{Alur Pelaksanaan Penelitian}

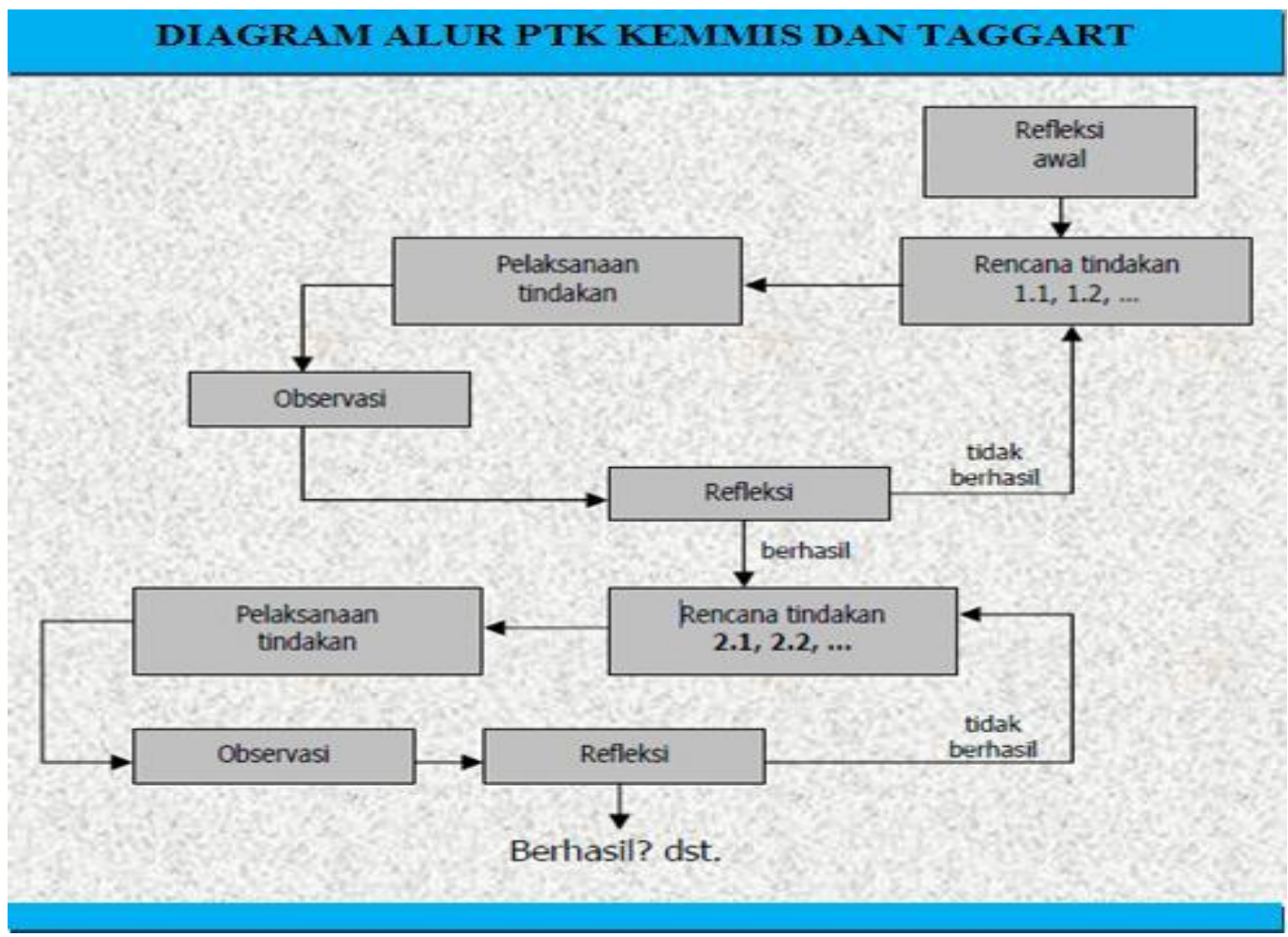

Gambar 2. Alur Pelaksanaan Penelitian. (Sugiyanto, 1995,p.5).

Teknik Pengumpulan Data

Teknik pengumpulan data dalam penelitian ini diperoleh melalui: (a) observasi dan catatan data lapangan, (b) wawancara, (c) hasil tes, dan (d) catatan hasil refleksi/diskusi yang dilakukan oleh peneliti dan mitra peneliti.

\section{Observasi dan Catatan Data Lapangan.}

Observasi dalam kegiatan PTK merupakan kegiatan pengamatan terhadap aktivitas yang dilakukan guru selama melaksanakan kegiatan belajar mengajar di kelas. Bentuk kegiatan observasi yang dilakukan dalam PTK ini menggunkanan model observasi terbuka. Adapun yang dimaksud observasi terbuka adalah melakukan pengamatan dengan mencatatkan segala sesuatu yang terjadi di kelas.

Hasil pengamatan dari mitra peneliti selanjutnya dijadikan catatan data lapangan. Hal ini sesuai dengan pendapat Wiriaatmadja (2005, p.125) yang menyatakan: "Sumber informasi yang sangat penting dalam penelitian ini (PTK) adalah catatan lapangan (field notes) yang dibuat oleh peneliti/mitra peneliti yang melakukan pengamatan atau observasi".

\section{Wawancara}

Wawancara menurut Denzin (Wiriaatmadja, 2005, p.117) adalah pertanyaan-perta- nyaan yang diajukan secara verbal kepada orang yang dianggap dapat memberikan informasi atau penjelasan hal-hal yang diperlu.

\section{Hasil Tes}

Hasil tes yang dimaksud adalah hasil berupa nilai yang diperoleh melalui penilaian akhir setiap siklus. Hasil ini dapat dijadikan bahan perbandingan antara hasil penilaian terdahulu dengan hasil penilaian setelah tindakan.

\section{Catatan Hasil Refleksi}

Catatan hasil refleksi adalah catatan yang yang diperoleh dari hasil refleksi yang dilakukan melalui kegiatan diskusi antara peneliti dan kolaborator. Hasil refleksi ini selain dijadikan bahan dalam penyusunan rencana tindakan selanjutnya juga dapat digunakan sebagai sarana untuk mengetahui telah tercapai tidaknya tujuan kegiatan penelitian ini.

\section{Teknik Analis Data}

Analisis data dalam PTKini dilakukan sejak awal, artinya analisis data dilakukan tahap demi tahap dimulai dari dialog awal, perencanaan dan siklus demi siklus. Hal ini sesuai dengan pendapat Miles dan Huberman (2001, p.139) bahwa ".... the ideal model for data collection and analysis is one that inter- 
weaves them form the beginning". Ini berarti model ideal dari pengumpulan data dan analisis adalah yang secara bergantian berlangsung sejak awal.

Kegiatan analisis data akan dilakukan mengacu pada pendapat Wiriaatmadja (2005, pp.135-151) dengan melakukan catatan refleksi, yakni pemikiran yang timbul pada saat mengamati dan merupakan hasil proses membandingkan, mengaitkan atau menghubungkan data yang ditampilkan dengan data sebelumnya. Gambaran hasil pelaksanaan refleksi tersebut dibuat dalam bentuk matrik agar terlihat lebih jelas dan mudah dipahami secara substansif.

\section{Rencana Tindakan}

Penelitian tindakan kelas direncanakan dilaksanakan dengan 2 siklus, setiap siklus dua kali tatap muka, setiap siklus terdiri dari empat tahap yaitu perencanaan, tindakan, observasi, refleksi.

\section{Perencanaan}

Peneliti berdialog dengan kolaborator melakukan penyatuan ide dan berdiskusi membahas masalah-masalah peningkatan teknik lompat jauh gaya menggantung dalam pembelajaran Penjasorkes yang terfokus pada siswa dalam penguasaan teknik lompat jauh gaya menggantung dengan metode bagian progresif. Sebelum melaksanakan tindakan, terlebih dahulu peneliti melakukan perencanaan. Berikut kegiatan yang dilakukan pada tahap perencanaan:

Penyusunan Rencana Pelaksanaan Pembelajaran (RPP) yang akan digunakan peneliti sebagai acuan dalam pelaksanaan pembelajaran. RPP tersebut memuat pendekatan pembelajaran lompat jauh gaya menggantung dengan metode bagian progresif.

Menyusun instrumen penelitian yang terdiri atas lembar observasi, pedoman penilaian dan rubrik penilaian.

Pelaksanaan tindakan

Hasil perencanaan metode bagian progresif akan membawa dampak peningkatan teknik lompat jauh gaya menggantung yang dilakukan setiap hari Senin. Implementasi tindakan dilakukan selama 4 minggu dan terbagi dalam 4 tatap muka.

\section{Observasi}

Kegiatan ini dilakukan oleh guru dan teman (guru penjas) dan dibekali pedoman observasi beserta kisi-kisinya dan catatan lapangan.

\section{Refleksi}

Refleksi dilakukan setiap akhir putaran dilakukan oleh peneliti dan teman peneliti untuk membahas hal-hal yang perlu penanganan segera. Evaluasi program tindakan metode bagian progresif dalam rangka meningkatkan teknik lompat jauh gaya menggantung. Sebagai upaya mencapai tingkat keberhasilan dan pencapaian tujuan tindakan. Berikut contoh matriks yang akan digunakan:

Tabel 1. Matrik Analisis Data

\begin{tabular}{|c|c|c|}
\hline $\begin{array}{c}\text { Teknik } \\
\text { Pengumpul } \\
\text { an Data }\end{array}$ & $\begin{array}{c}\text { Deskripsi } \\
\text { Pelaksanaan dan } \\
\text { Hasil yang Diperoleh }\end{array}$ & $\begin{array}{l}\text { Analisis- } \\
\text { Refleksi }\end{array}$ \\
\hline \multicolumn{3}{|l|}{$\begin{array}{l}\text { Observasi } \\
\text { Wawancara } \\
\text { Hasil Tes }\end{array}$} \\
\hline \multicolumn{3}{|c|}{$\begin{array}{l}\text { Keterangan: } \\
\text { Kolom deskripsi pelaksanaan dan hasil yang } \\
\text { diperoleh akan diisi data disksripsi pelaksaaan } \\
\text { kegiatan observasi itu sendiri (terutama ham- } \\
\text { batan-hambatan dalam pelaksaaannya) dan di- } \\
\text { isi dengan data hasil dari pelaksanaan kegiatan } \\
\text { pengumpulan data dengan teknik tersebut. Se- } \\
\text { dangkan kolom analisis dan refleksi diisi de- } \\
\text { ngan data hasil refleksi dan analisis yang dila- } \\
\text { kukan melalui kegiatan diskusi antara peneliti } \\
\text { dan kolaborator. }\end{array}$} \\
\hline
\end{tabular}

\section{Hasil Penelitian dan Pembahasan}

\section{Data Awal Penelitian}

Pada bab ini akan disajikan data hasil penelitian dan hasil analisis data yang diuraikan studi awal (hasil dialog dan hasil perencanaan) tindakan dan persiklus penelitian. Adapun jumlah siklus penelitian ini adalah 2 siklus. Hal ini disebabkan perolehan data dari 2 siklus penelitian telah memberikan gambaran yang cukup signifikan pencapaian tujuan penelitian. Artinya, data yang diperoleh siklus demi siklus menunjukkan pada peningkatan hasil belajar siswa yang menjadi objek dalam penelitian ini.

Kegiatan ini dimulai dengan pembicaraan antara peneliti dengan guru pendidikan jasmani dan kepala sekolah yang terpusat pada pembelajaran pendidikan jasmani, khususnya 
pada pembelajaran lompat jauh gaya menggantung di sekolah. Hasil diskusi dan wawancara tersebut antara lain: (1) Berdasarkan pengamatan yang dilakukan, bahwa seluruh siswa Kelas X F SMAN 1 Ceper Klaten sangat menggemari pelajaran pendidikan jasmani. Menurut; (2) kepala sekolah, hal ini harus dipelihara dan terus dijaga agar para siswa tetap memiliki motivasi tinggi dalam mengikuti proses belajar mengajar, dan berharap bisa menular pada pelajaran lain; (3) Dalam kegiatan belajar mengajar pendidikan jasmani metode yang dominan digunakan adalah metode komando, guru sangat besar peranannya dalam memberikan pembelajaran, siswa dituntut untuk mengikuti perintah yang diinstruksikan oleh guru sehingga pengalaman gerak yang didapat siswa minim; (4) Selain itu siswa dalam konteks sosialnya kurang sebagai contoh siswa kurang berkomunikasi dengan teman karena terfokus pada tugas gerak yang diberikan oleh guru, siswa akan terlihat bersemangat bagi siswa yang mampu menguasai tugas gerak yang diberikan oleh guru tetapi siswa terlihat tidak bersemangat karena siswa tersebut kurang mampu melakukan tugas gerak yang diberikan oleh guru sehingga terlihat timpang. Seharusnya yang dilakukan oleh guru adalah memberikan pembelajaran yang menarik sehingga siswa terlihat antusias untuk melakukannya jangan memberikan pembelajaran yang monoton kepada siswa, di samping itu guru harus memperhatikan tujuan dan manfaat pembelajaran yang diberikan.

Data awal penelitian untuk siswa yang belum mencapai KKM berjumlah 14 orang dengan nilai yang paling rendah 31,25 . Siswa yang sudah mencapai KKM berjumlah 9 orang dengan nilai tertinggi 81,25. Dengan rata-rata nilai 62,50. Lebih lengkap dapat di lihat pada lampiran 15 halaman 159.

Data yang peneliti dapat bukan hanya dari penilaian tetapi peneliti juga mencatat setiap masalah yang timbul pada siswa, di antaranya adalah: (1) Siswa tidak semuanya aktif, lebih didominasi oleh siswa laki-laki yang lebih antusias dan siswa perempuan hanya menjadi pelengkap saja; (2) Siswa kesulitan dalam melakukan tolakan, karena belum mengetahui kaki kanan atau kaki kiri yang digunakan untuk tolakan; (3) Siswa tidak bisa menghargai teman yang kurang mampu melakukan tugas gerak, sehingga siswa menjadi minder, malas dan tidak bersemangat.
Dari hasil pembicaraan, diskusi dan wawancara dengan kolabolator dan kepala sekolah, peneliti mencoba mengajukan suatu metode pembelajaran pendidikan jasmani yang menurut belum pernah dilakukan yaitu metode bagian progresif, untuk dapat mengatasi permasalahan tersebut di atas. Kolaborator dan kepala sekolah sangat antusias menyambut gagasan ini.

\section{Siklus I Pertemuan ke 1}

\section{Perencanaan}

Dalam studi awal peneliti melakukan dialog dengan teman sejawat tentang pembelajaran teknik lompat jauh gaya menggantung. Dialog dengan teman sejawat dan kajian pustaka mendapatkan hasil bahwa penguasaan teknik lompat jauh gaya menggantung siswa dapat dilaksanakan melalui pembelajaran yang menggunakan metode bagian progresif. Menindaklanjuti hasil data awal di atas, selanjutnya peneliti menyusun rencana pembelajaran pendidikan jasmani dengan materi permainan lompat jauh gaya menggantung yang disampaikan melalui penerapan metode bagian progresif. Kemudian disepakati oleh peneliti dan kolaborator serangkaian perencanaan pembelajarannya, antara lain: (a) Menetapkan materi permainan lompat jauh gaya menggantung yang akan diberikan pada siswa, disesuaikan dengan alokasi waktu pelajaran pendidikan jasmani; (b) Membuat rencana pelaksanaan pembelajaran, adapun rencana pelaksanaan pembelajaran terdapat pada lampiran 11 hal 130; (c) Mempersiapkan alat-alat yang digunakan dalam proses belajar mengajar permainan lompat jauh gaya menggantung seperti count/patok, ban bekas, peluit; (d) Apersepsi dilaksanakan dengan cara menjelaskan secara sepintas tentang pengertian dan tujuan penerapan metode bagian progresif dalam pembelajaran lompat jauh gaya menggantung; (e) Dalam pemanasan guru memberikan permainan-permainan terfokus pada pembelajaran lompat jauh gaya menggantung; (f) Pada kegiatan inti guru memberikan permainan lompat jauh gaya menggantung; (g) Dalam kegiatan belajar mengajar guru bertindak sebagai fasilitator, apabila ada siswa yang mengalami kesulitan dalam proses belajar pembelajaran ini guru memberikan penjelasan seperlunya; (h) Menyiapkan format penilaian ketrampilan teknik (aspek psikomotor), catatan lapangan dan dokumentasi 
Tabel 2. Rencana Pelaksanaan Pembelajaran I

\section{Pendahuluan (20 menit)}

- Membariskan siswa di lapangan

- Berdo’a

- Menjelaskan tentang metode bagian progresif dalam pembelajaran lompat jauh gaya menggantung

- Mengecek kehadiran siswa dan menegur siswa yang tidak berpakaian olahraga

- Memberikan pemanasan dengan aktivitas permainan sebelum ke kegiatan inti (permainan englek)

\section{Kegiatan Inti (50 menit)}

- Memberikan penjelasan tentang permainan dalam kegiatan inti

- Guru membagi dua kelompok

- Guru melakukan pendampingan dengan mengkoreksi setiap siswa gerakan siswa yang kurang baik.

- Mengarahkan siswa agar siswa tidak kebingungan tentang apa yang harus mereka lakukan

a) Pembukaan

1) Menjelaskan tentang lompat jauh

Lompat jauh adalah gerakan ancang-ancang dengan lari secepatnya kemudian menumpu pada papan tolakan dengan hentakan satu kaki, kemudian tubuh melayang di udara sejauh-jauhnya dan mendarat dengan kedua kaki dengan keseimbangan yang baik.

2) Menjelaskan gaya yang ada dalam lompat jauh

Dalam lompat jauh terdapat tiga macam gaya yaitu: lompat jauh gaya jongkok (tuck), gaya menggantung (hang style), dan gaya jalan di udara (walking in the air). Gaya-gaya lompat jauh mengatur sikap badan sewaktu melayang di udara.

3) Menjelaskan teknik lompat jauh gaya menggantung.

Secara teknik pada lompat jauh gaya menggantung meliputi empat masalah yaitu: cara melakukan awalan, tolakan (tumpuan), melayang di udara dan pendaratan

b) Analisis

1) Menjelaskan dan memberikan contoh tentang awalan

Tujuan: Guna mencapai keepatan maximum yang terkontrol

(a) Panjang lari ancang-ancang bervariasi antara 10-15 langkah

(b) Teknik lari adalah mirip dengan lari sprint

(c) Kecepatan meningkat terus menerus sampai mencapai balok tumpuan.

2) Menjelaskan dan memberikan contoh tentang tolakan

Tujuan: Guna memaximalkan kecepatan vertical dan guna memperkecil hilangnya kecepatan horizontal

(a) Penancapan kaki adalah aktif dan cepat dengan suatu gerakan ke bawah dan ke belakang

(b) Waktu bertolak adalah dipersingkat, pembengkokkan minimum dari kaki penumpu

(c) Paha kaki bebas didorong ke posisi horisntal

(d) Sendi-sendi mata kaki, lutut dan pinggang diluruskan

3) Menjelaskan dan memberikan contoh tentang melayang

Tujuan: untuk mempersiapkan suatu pendaratan yang efisien.

(a) Kaki bebas diturunkan oleh gerak putaran pada sendi pinggang

(b) Pinggang didorong ke depan

(c) Kaki penumpu adalah paralel dengan kaki bebas

(d) Lengan-lengan ada dalam posisi ke atas dan ke belakang

4) Menjelaskan dan memberikan contoh tentang mendarat

Tujuan: Untuk memperkecil hilangnya jarak lompatan

(a) Kedua kaki adalah hampir sepenuhnya diluruskan

(b) Badan dibengkokkan ke depan

(c) Lengan-lengan ditarik ke belakang

(d) Pinggang didorong ke depan menuju ke titik sentuh-tanah

c) Latihan

Memberikan latihan gerak teknik lompat jauh gaya menggantung secara berurutan dimulai dari awalan, tolakan, melayang, mendarat

Latihan tahap awalan

Lompat berturut-turut melewati rintangan

(1) Gunakan lari ancang-ancang yang berjarak 6-8 m

(2) Mendaratlah pada kaki depan

(3) Gunakan suatu irama lari 3 langkah

Tujuan: untuk bertolak dari suatu ancang-ancang pendek dan memperbaiki posisi bertolak

Latihan tahap tolakan 

Lompatan marka jauh
(1) Gunakan 5-7 langkah ancang-ancang
(2) Pertahankan posisi bertumpu di udara
(3) Pertahankan posisi bertumpu
(4) Mendarat dalam posisi langkah (marka-jauh)
(5) Tujuan: untuk menekankan gerakan bertolak dan membekukan posisi tumpuan
Latihan tahap melayangTeknik duduk-luncur dari suatu mimbar

(1) Gunakan 5-7 langkah ancang-ancang

(2) Pertahankan posisi bertolak di udara

(3) Luruskan kaki depan sebelum mendarat

(4) Tarik kaki tumpu ke depan atas

(5) Mendarat dengan kaki parallel

(6) Tujuan: Untuk mempratekkan teknik dengan dibantu tumpuan

Latihan tahap mendarat

urutan gerak keseluruhan dari suatu ancang-ancang penuh

(1) Lari kembali dari papan tumpu

(2) Bertolak pada tempat yang tepat (20-30 m)

(3) Mitra latih memberi tanda tempat bertolak

(4) Lari ancang-ancang dari tempat ini

(5) Jangan merubah panjang langkah pada percobaan pertama

(6) Lakukan lari ancang-ancang dan tempat start yang benar

(7) Tujuan: Untuk menentukan panjang lari ancang-ancang dan rangkaikan gerakan selengkapnya.

Sistesis

1) Siswa diberi tugas gerak untuk melakukan teknik lompat jauh gaya menggantung secara keseluruhan

2) Memberikan umpan balik kepada siswa

3) Memberikan motivasi kepada siswa

4) Menberikan koreksi secara individu atau klasikal

\section{Kegiatan Penutup (20 menit)}

- Mengumpulkan siswa, menjelaskan kembali tentang kegiatan yang telah dilakukan guru menanyakan kepada siswa tentang pemahaman siswa tentang materi lompat jauh gaya menggantung.

- Mengkoreksi pembelajaran yang telah dilakukan oleh siswa

- Guru melakukan penilaian hasil belajar siswa dengan melihat siswa melakukan teknik lompat jauh gaya menggantung.

- Melakukan penenangan terhadap siswa

- Berdo'a dan membubarkan siswa kembali ke kelas

- Membereskan peralatan

\section{Pelaksanaan}

Pada tahap ini kegiatan yang dilaksanakan berdasarkan perencanaan tindakan yang telah ditetapkan, yaitu melaksanakan pembelajaran sesuai rencana pembelajaran yang telah dibuat. Fokus dalam pembelajaran ini adalah meningkatkan keterampilan teknik lompat jauh gaya menggantung (aspek psikomotor) yang dimiliki siswa. Pembelajaran dilakukan pada hari Senin tanggal 2 Juni 2012 mulai pukul 07:00 hingga pukul 08:45 WIB di halaman/ lapangan upacara SMANegeri 1 Ceper Klaten.

Setelah semua siswa berada di lapangan, siswa terlihat bersemangat untuk mengikuti pelajaran pendidikan jasmani tetapi terlihat tidak kondusif, ada beberapa siswa yang mengganggu siswa lain sehingga menyulut pertengkaran antarsiswa, guru berusaha menguasai kelas dengan memberikan permainan-permainan yang menarik agar siswa kondusif sebelum memberikan materi yaitu permainan gajah-se- mut. Cara bermain pemimpin permaianan meminta peserta berdiri melingkar. Jika guru mengatakan "Gajah itu....", maka siswa menjawab "Besar", tapi membentuk lingkaran kecil dengan tangan di depan dada. Sebaliknya, jika guru mengatakan "Semut itu...", maka siswa menjawab "kecil" dengan membentuk lingkaran besar menggunakan tangan. Permainan menjadi seru jika guru menyampaikan intruksi secara cepat.

Guru memberikan materi yaitu menerapkan metode bagian progresif dalam pembelajaran lompat jauh gaya menggantung, dengan menitikberatkan penguasaan teknik dalam materi yang diberikan semua berbentuk permainan sehingga pembelajaran yang diberikan menarik untuk anak tetapi pada saat memberikan pengertian dan tujuan metode bagian progresif siswa terlihat bingung dan banyak siswa yang bertanya.

Pada pemanasan guru memberikan permainan engklek (Jawa) tujuan dari permain- 
an ini untuk meningkatkan kerja sama, komunikasi, kelincahan, kecepatan sebelum menuju ke kegiatan inti. Dalam permainan ini siswa terlihat bersemangat dalam melakukannya tetapi dilain pihak banyak siswa yang melanggar peraturan yang diberikan dalam permainan.

Cara bermain engklek sebagai berikut peserta permainan ini melompat menggunakan satu kaki di setiap petak-petak yang telah digambar sebelumnya di tanah. Untuk dapat bermain, setiap anak harus berbekal gacuk yang biasanya berupa sebentuk pecahan genting, yang juga disebut kreweng (pecahan genting), yang dalam permainan, kreweng ini ditempatkan di salah satu petak yang tergambar di tanah dengan cara dilempar, petak yang ada gacuknya tidak boleh diinjak/ditempati oleh setiap pemain, jadi para pemain harus melompat ke petak berikutnya dengan satu kaki mengelilingi petak-petak yang ada. Pemain yang telah menyelesaikan satu putaran terlebih dahulu, berhak memilih sebuah petak untuk dijadikan "sawah" yang artinya di petak tersebut pemain yang bersangkutan dapat menginjak petak itu dengan kedua kaki, sementara pemain lain tidak boleh menginjak petak itu selama permainan. Peserta yang memiliki kotak paling banyak adalah yang akan memenangkan permainan ini.

Pada kegiatan inti guru memberikan materi lompat jauh gaya menggantung dengan metode bagian progresif dengan memberikan contoh dari latihan awalan, tolakan, melayang, dan mendarat. Teknik diberikan tahap demi tahap dari yang mudah ke yang komplek, dan diulang-ulang 3-4 kali sehingga anak dapat menguasai teknik dasar lompat jauh gaya menggantung.

selesai memberikan tahapan awalan, tolakan, melayang, dan mendarat, maka dievaluasi dengan mengamati siswa melakukan lompat jauh gaya menggantung dengan teknik yang telah diberikan. Dari hasil analisis penilaian siswa mengalami kesulitan pada tahap tolakan yaitu anak menyesuaikan langkah kaki dari awalan ke papan tolakan harus menggunakan kaki kanan. dan saat melakukan tolakan anak menggunakan kaki kiri. Umumnya siswa tidak berkaki kidal biasanya kaki terkuat adalah kaki kanan, sehingga siswa merasa salah langkah saat melakukan tolakan.

\section{Observasi}

Hasil pembelajaran lompat jauh gaya menggantung dilakukan dengan penerapan me- tode bagian progresif, tampak memberikan suasana baru terhadap suasana pembelajaran. Hal ini terjadi karena siswa baru pertama kali melakukan pembelajaran lompat jauh gaya menggantung dengan metode bagian progresif.

Penilaian tersebut dilakukan secara individu yang kemudian dihitung dan didapat rata-rata 23 siswa. Di lihat dari data awal yang diperoleh ternyata setelah menggunakan metode bagian progresif dalam pembelajaran lompat jauh gaya menggantung mampu meningkatkan keterampilan teknik (aspek psikomotor). Diperoleh nilai rata-rata tes ketrampilan teknik (aspek psikomotor) yaitu 68,75 mengalami peningkatan 6,25 . Namun nilai rata-rata siswa belum mencapai kriteria ketuntasan minimal yaitu 75. Dari 23 siswa yang mencapai KKM ada 11 siswa dan yang belum memenuhi KKM ada 12 siswa. Untuk awalan 5 orang yang terlihat kurang maksimal saat berlari (kurang bertenaga). Siswa yang kesulitan saat melakukan tolakan ada 9 siswa, orang terlihat pergantian kaki saat akan melakukan tolakan.

\section{Refleksi}

Kegiatan refleksi dilakukan segera setelah pembelajaran selesai, hal ini bertujuan agar persepsi tentang pembelajaran yang dilaksanakan masih terasa segar dalam ingatan. Di dalam refleksi ini dikaji data yang telah diperoleh dengan instrumen yang telah disepakati pada tahap pertemuan atau diskusi awal. Dari hasil analisis dan diskusi dengan kolabolator dapat dijadikan bahan refleksi untuk perbaikan pembelajaran dan dituangkan dalam pembelajaran sebagai berikut: (1) Siswa masih ada yang belum bersemangat dalam pembelajaran; (2) Siswa belum terbiasa dengan metode bagian progresif sehingga masih memerlukan waktu lama dalam melaksanakan gerak teknik; (3) Beberapa siswa masih ada yang duduk dalam pembelajaran sehingga memperlambat kegiatan pembelajaran.

\section{Siklus I Pertemuan ke 2}

\section{Perencanaan}

Peneliti melakukan dialog dengan kolaborator tentang pembelajaran teknik lompat jauh gaya menggantung berdasarkan refleksi, dan menghasilkan beberapa hal antara lain: (a) Menindaklanjuti hasil siklus I pertemuan 1 di atas, selanjutnya peneliti menyusun rencana pembelajaran pendidikan jasmani dengan materi permainan lompat jauh gaya menggan- 
tung yang disampaikan melalui penerapan metode bagian progresif; (b) Menetapkan materi permainan lompat jauh gaya menggantung yang akan diberikan pada siswa, disesuaikan dengan alokasi waktu pelajaran pendidikan jasmani; (c) Membuat rencana pelaksanaan pembelajaran; (d) Mempersiapkan alat-alat yang digunakan dalam proses belajar mengajar permainan lompat jauh gaya menggantung seperti count/patok, ban bekas, peluit; (e) Apersepsi dilaksanakan dengan cara menjelaskan secara sepintas tentang pengertian dan tujuan penerapan metode bagian progresif dalam pembel- ajaran lompat jauh gaya menggantung; (f) Dalam pemanasan guru memberikan permainan-permainan terfokus pada pembelajaran lompat jauh gaya menggantung; (g) Pada kegiatan inti guru memberikan permainan lompat jauh gaya menggantung dengan metode bagian progresif; (h) Dalam kegiatan belajar mengajar guru bertindak sebagai fasilitator, apabila ada siswa yang mengalami kesulitan dalam proses belajar pembelajaran ini guru memberikan penjelasan seperlunya; (i) Menyiapkan format penilaian keterampilan teknik catatan lapangan dan dokumentasi

\section{Tabel 3. Rencana Pelaksanaan Pembelajaran II}

\section{Pendahuluan (20 menit)}

- Membariskan siswa dilapangan

- Berdo'a

- Menjelaskan tentang metode bagian progresif dalam pembelajaran lompat jauh gaya menggantung

- Mengecek kehadiran siswa dan menegur siswa yang tidak berpakaian olahraga

- Memberikan pemanasan dengan aktivitas permainan sebelum ke kegiatan inti (permainan englek)

\section{Kegiatan Inti (50 menit)}

- Memberikan penjelasan tentang permainan dalam kegiatan inti

- Guru membagi dua kelompok.

- Guru melakukan pendampingan dengan mengkoreksi setiap siswa gerakan siswa yang kurang baik.

- Mengarahkan siswa agar siswa tidak kebingungan tentang apa yang harus mereka lakukan

a) Pembukaan

1) Menjelaskan lebih detail tentang teknik lompat jauh gaya menggantung

2) Menjelaskan perbedaan gaya menggantung dengan gaya jongkok serta gaya jalan di udara

b) Analisis

1) Memberikan contoh tentang awalan

2) Memberikan contoh tentang tolakan.

3) Memberikan contoh tentang melayang

4) Memberikan contoh tentang mendarat

c) Latihan

Memberikan latihan gerak teknik lompat jauh gaya menggantung secara berurutan dimulai dari awalan, tolakan, melayang, mendarat

1) Latihan tahap awalan

i. Lari sprint dari standing start

ii. Latihan langkah lari panjang pendek

2) Latihan tahap tolakan

i. Menolak dengan satu kaki

ii. Menolak dari posisi lari jarak pendek

3) Latihan tahap melayang

i. Latihan melayang dari awalan jarak pendek.

ii. Latihan mengantung dengan melentingkan badan di tepi bak lompat

4) Latihan tahap mendarat

i. Latihan mendarat dengan 2 kaki rapat

ii. Latihan mendarat ke dalam lingkaran

d) Sintesis

1) Siswa diberi tugas gerak untuk melakukan teknik lompat jauh gaya menggantung secara keseluruhan

2) Memberikan umpan balik kepada siswa

3) Memberikan motivasi kepada siswa

4) Menberikan koreksi secara individu atau klasikal

\section{Kegiatan Penutup (20 menit)}

- Mengumpulkan siswa, menjelaskan kembali tentang kegiatan yang telah dilakukan guru menanyakan kepada siswa tentang pemahaman siswa tentang materi lompat jauh gaya menggantung.

- Mengkoreksi pembelajaran yang telah dilakukan oleh siswa 
- Guru melakukan penilaian hasil belajar siswa dengan melihat siswa melakukan teknik lompat jauh gaya menggantung.

- Melakukan penenangan terhadap siswa

- Berdo'a dan membubarkan siswa kembali ke kelas

- Membereskan peralatan

\section{Pelaksanaan}

Pada tahap ini kegiatan yang dilaksanakan berdasarkan perencanaan tindakan yang telah ditetapkan, yaitu melaksanakan pembelajaran sesuai rencana pembelajaran yang telah dibuat. Fokus dalam pembelajaran ini adalah meningkatkan keterampilan teknik lompat jauh gaya menggantung (aspek psikomotor) yang dimiliki siswa. Pembelajaran dilakukan pada hari Senin tanggal 9 Juni 2012 mulai pukul 07:00 hingga pukul 08:45 WIB di halaman/ lapangan upacara SMANegeri 1 Ceper Klaten.

Setelah semua siswa berada di lapangan, siswa terlihat bersemangat untuk mengikuti pelajaran pendidikan jasmani tetapi terlihat tidak kondusif, ada beberapa siswa yang mengganggu siswa lain sehingga menyulut pertengkaran antarsiswa, guru berusaha menguasai kelas dengan memberikan permainan-permainan yang menarik agar siswa kondusif sebelum memberikan materi yaitu permainan gajah-semut. Cara bermain Pemimpin permainan meminta peserta berdiri melingkar. Jika pemimpin mengatakan "Gajah itu....", maka peserta menjawab "Besar", tapi membentuk lingkaran kecil dengan tangan di depan dada. sebaliknya, jika pemimpin mengatakan "Semut itu...", maka peserta menjawab "kecil" dengan membentuk lingkaran besar menggunakan tangan. Permainan menjadi seru jika pemimpin menyampaikan intruksi secara cepat.

Guru memberikan materi yaitu menerapkan metode bagian progresif dalam pembelajaran lompat jauh gaya menggantung, dengan menitikberatkan penguasaan teknik dalam materi yang diberikan semua berbentuk permainan sehingga pembelajaran yang diberikan menarik untuk anak tetapi pada saat memberikan pengertian dan tujuan metode bagian progresif siswa terlihat bingung dan banyak siswa yang bertanya.

Pada pemanasan guru memberikan permainan engklek tujuan dari permainan ini untuk meningkatkan kerja sama, komunikasi, kelincahan, kecepatan sebelum menuju ke kegiatan inti. Dalam permainan ini siswa terlihat bersemangat dalam melakukannya tetapi dilain pihak banyak siswa yang melanggar peraturan yang diberikan dalam permainan.
Cara bermain adalah peserta permainan ini melompat menggunakan satu kaki di setiap petak-petak yang telah digambar sebelumnya di tanah. Untuk dapat bermain, setiap anak harus berbekal gacuk yang biasanya berupa sebentuk pecahan genting, yang juga disebut kreweng, yang dalam permainan, kreweng ini ditempatkan di salah satu petak yang tergambar di tanah dengan cara dilempar, petak yang ada gacuknya tidak boleh diinjak/ditempati oleh setiap pemain, jadi para pemain harus melompat ke petak berikutnya dengan satu kaki mengelilingi petak-petak yang ada. Pemain yang telah menyelesaikan satu putaran terlebih dahulu, berhak memilih sebuah petak untuk dijadikan "sawah" mereka, yang artinya di petak tersebut pemain yang bersangkutan dapat menginjak petak itu dengan kedua kaki, sementara pemain lain tidak boleh menginjak petak itu selama permainan. Peserta yang memiliki kotak paling banyak adalah yang akan memenangkan permainan ini.

Pada kegiatan inti guru memberikan materi lompat jauh gaya menggantung dengan metode bagian progresif dengan memberikan contoh dari latihan awalan, tolakan, melayang, dan mendarat. Teknik diberikan tahap demi tahap dari yang mudah ke yang komplek, dan diulang-ulang 3-4 kali sehingga anak dapat menguasai teknik dasar lompat jauh gaya menggantung.

Setelah selesai memberikan tahapan awalan, tolakan, melayang, dan mendarat, maka dievaluasi dengan mengamati siswa melakukan lompan jauh gaya menggantung dengan teknik yang telah diberikan. Dari hasil analisis penilaian siswa mengalami kesulitan pada tahap tolakan yaitu anak menyesuaikan langkah kaki dari awalan ke papan tolakan harus menggunakan kaki kanan. dan saat melakukan tolakan anak menggunakan kaki kiri. Umumnya siswa tidak berkaki kidal biasanya kaki terkuat adalah kaki kanan, sehingga siswa merasa salah langkah saat melakukan tolakan.

\section{Observasi}

Hasil siklus I pembelajaran lompat jauh gaya menggantung dilakukan dengan penerapan metode bagian progresif, tampak memberikan suasana baru terhadap suasana 
pembelajaran. Hal ini terjadi karena mereka baru pertama kali melakukan pembelajaran lompat jauh gaya menggantung dengan metode bagian progresif.

Penilaian tersebut dilakukan secara individu yang kemudian dihitung dan didapat rata-rata 23 siswa. Di lihat dari data awal yang diperoleh ternyata setelah menggunakan metode bagian progresif dalam pembelajaran lompat jauh gaya menggantung mampu meningkatkan keterampilan teknik (aspek psikomotor). Diperoleh nilai rata-rata tes ketrampilan teknik (aspek psikomotor) yaitu 72,75 mengalami peningkatan 6,25 . Namun nilai rata-rata siswa belum mencapai kriteria ketuntasan minimal yaitu 75. Dari 23 siswa yang mencapai KKM ada 12 siswa dan yang belum memenuhi KKM ada 11 siswa. Untuk awalan 5 orang yang terlihat kurang maksimal. Data lebih lengkap dapat dilihat pada lampiran 17 halaman 161.

\section{Refleksi}

Kegiatan refleksi dilakukan segera setelah pembelajaran selesai, hal ini bertujuan agar persepsi tentang pembelajaran yang dilaksanakan masih terasa segar dalam ingatan. Di dalam refleksi ini dikaji data yang telah diperoleh dengan instrumen yang telah disepakati pada tahap pertemuan atau diskusi awal. Dari hasil analisis dan diskusi dengan kolabolator dapat dijadikan bahan refleksi untuk perbaikan pembelajaran dan dituangkan dalam pembela- jaran yaitu sebagai berikut: (1) Ada peningkatan pada pembelajaran, baik dilihat dari pengelolaan kelas, maupun proses belajar mengajar menggunakan metode bagian progresif. Penggunaan waktu lebih efektif, karena para siswa telah mendapatkan informasi lebih jelas dari guru, dan telah memperoleh pengalaman dari pembelajaran; (2) Pada saat salah satu siswa melakukan gerakan teknik siswa yang lain tidak memperhatikan, berbicara sendiri; (3) Siswa masih ada yang kurang bersemangat dalam pembelajaran terutama putri.

Peneliti juga mencatat setiap masalah yang timbul pada siswa, di antaranya adalah: (1) Pada saat pelajaran dibuka melalui apersepsi, guru memaparkan tentang pendekatan metode bagian progresif dan menjelaskan pemanasan beserta inti pembelajaran yang akan diberikan kepada siswa. Mereka terlihat kebingungan menerima penjelasan materi yang diterima sehingga siswa banyak bertanya dan memakan waktu yang seharusny 7-10 menit menjadi panjang, menghabiskan waktu 15 menit. Hal ini wajar karena mereka baru mendapatkan pembelajaran dengan metode bagian progresif; (2) Pada saat pelaksanaan kegiatan belajar menggunakan metode bagian progresif siswa terlihat masih canggung. Hal ini bisa dipahami karena selama ini dalam pembelajaran pendidikan jasmani belum pernah mendapatkan materi dengan metode bagian progresif

Tabel 4. Perbedaan Antara Pertemuan 1 dan 2

\begin{tabular}{|c|c|c|}
\hline Uraian & Pertemuan 1 & Pertemuan 2 \\
\hline \multicolumn{3}{|l|}{ Materi } \\
\hline Latihan tahap awalan & $\begin{array}{l}\text { Lompat berturut-turut melewati rintang-an. } \\
\text { Tujuan: untuk bertolak dari ancang-ancang } \\
\text { pendek dan memperbaiki posisi bertolak. }\end{array}$ & $\begin{array}{l}\text { Lari sprint dari standing start dan } \\
\text { latihan langkah lari panjang pendek. }\end{array}$ \\
\hline Latihan tahap tolakan & $\begin{array}{l}\text { Lompatan marka jauh. Tujuan: untuk me- } \\
\text { nekankan gerakan bertolak dan membeku- } \\
\text { kan posisi tumpuan. }\end{array}$ & $\begin{array}{l}\text { Menolak dengan satu kaki dan dari } \\
\text { posisi lari jarak pendek. }\end{array}$ \\
\hline Latihan tahap melayang & $\begin{array}{l}\text { Teknik duduk-luncur dari suatu mimbar. } \\
\text { Tujuan: Untuk mempratekkan teknik de- } \\
\text { ngan dibantu tumpuan. }\end{array}$ & $\begin{array}{l}\text { Latihan melayang dari awalan jarak } \\
\text { pendek dan latihan mengantung de- } \\
\text { ngan melentingkan badan di tepi bak } \\
\text { lompat. }\end{array}$ \\
\hline Latihan tahap mendarat & $\begin{array}{l}\text { Urutan gerak keseluruhan dari suatu } \\
\text { ancang-ancang penuh. Tujuan: Untuk } \\
\text { menentukan panjang lari ancang-ancang } \\
\text { dan rangkaikan gerakan selengkapnya }\end{array}$ & $\begin{array}{l}\text { Latihan mendarat dengan } 2 \text { kaki rapat } \\
\text { dan latihan mendarat ke dalam ling- } \\
\text { karan }\end{array}$ \\
\hline Tujuan & $\begin{array}{l}\text { Pada pertemuan ke } 1 \text { materi yang diberi- } \\
\text { kan bertujuan untuk mengenalkan lompat } \\
\text { jauh secara menyeluruh. Dari teknik } \\
\text { awalan, tolakan, melayang, dan mendarat } \\
\text { dari gerakan yang sederhana ke rumit. }\end{array}$ & $\begin{array}{l}\text { Pada pertemuan ke } 2 \text { materi yang } \\
\text { diberikan bertujuan untuk pendalaman } \\
\text { teknik lompat jauh gaya menggantung, } \\
\text { dan memperjelas perbedaan antara } \\
\text { gaya menggantung dengan gaya jalan } \\
\text { di udara atau gaya jongkok. }\end{array}$ \\
\hline
\end{tabular}


Hasil dari proses pembelajaran lompat jauh gaya menggantung dari data awal, pertemuan 1, pertemuan 2 terjadi peningkatan siswa yang memperoleh KKM, namun hasil yang diharapkan belum tercapai.

Dari hasil pembelajaran siklus 1 belum sesuai harapan, maka perlu dilanjutkan ke siklus berikutnya yaitu siklus 2 .

Hipotesis yang diajukan untuk siklus 2 adalah metode bagian progresif yang dipadukan dengan permainan hijau hitam dan engklek dapat meningkatkan hasil pembelajaran lompat jauh gaya menggantung di Kelas X F SMAN 1 Ceper Klaten Tahun Ajaran 2011/2012.

Siklus 2 pertemuan ke 1

\section{Perencanaan}

Pemberian Siklus II dirancang berdasarkan hasil refleksi terhadap Siklus I yang dianggap masih ada kekurangan serta kelemahan yang belum sesuai dengan target proses maupun hasil pada seluruh tahapan kegiatan pembelajaran. Pada dasarnya perencanaan pembelajaran tindakan dua ini sama dengan perencanaan tindakan satu. Secara umum siswa masih ragu-ragu, masih bingung untuk melakukan pembelajaran yang diberikan sehingga memerlukan dorongan motivasi dari guru, baik dari penguatan ataupun arahan-arahan yang dapat meningkatkan percaya diri anak.

\section{Pelaksanaan}

Kegiatan yang dilaksanakan berdasarkan perencanaan tindakan yang telah ditetapkan, yaitu melaksanakan pembelajaran sesuai rencana pembelajaran yang telah dibuat. Pem- belajaran dilaksanakan hari senin tanggal 16 Juni 2012 mulai pukul 07:00 hingga pukul 08:30 WIB. pada apersepsi lebih difokuskan pada peningkatan motivasi melalui arahanarahan yang jelas tentang segala sesuatu hal yang berkaitan dengan lompat jauh gaya menggantung.

Setelah semua siswa berada di lapangan siswa terlihat lebih kondusif, karena pada pertemuan sebelumnya siswa kurang puas melakukan pembelajaran yang diberikan sehingga siswa terlihat siap untuk melaksanakan pembelajaran pendidikan jasmani pada hari itu. Pada pemanasan guru memberikan permainan hijau-hitam, dalam permainan ini siswa terlihat bersemangat lebih sportif dalam melakukannya dengan tidak melanggar peraturan yang diberikan sehingga permainan tersebut menjadi lebih efektif, komunikasi antarsiswa pun lebih terjalin dengan baik walaupun masih terlihat malumalu. Siswa dibagi menjadi 2 tim yaitu tim hijau dan hitam. Apabila guru menyebut hitam maka kelompok hitam menangkap hijau dan hijau menghindar lari ke belakang sampai batas kun, begitu sebaliknya. Siswa yang dapat menangkap lawanya mendapat skor.

Pada kegiatan inti guru memberikan permainan lompat jauh gaya menggantung modifikasi yang diberi nama menyundul bola, kurang bisa ataupun kurang menyukai permainan lompat jauh gaya menggantung menjadi terlihat tidak bersemangat/malas untuk mengikuti pembelajaran yang diberikan tetapi pada pertemuan kali ini siswa yang kurang mampu berusah untuk mencoba dan terus mencoba untuk memberikan partisipasi dalam pembelajaran.

Tabel 5. Rencana Pelaksanaan Pembelajaran III

\section{Pendahuluan (20 menit)}

- Membariskan siswa dilapangan

- Berdo’a

- Menjelaskan tentang metode bagian progresif dalam pembelajaran lompat jauh gaya menggantung

- Mengecek kehadiran siswa dan menegur siswa yang tidak berpakaian olahraga

- Memberikan pemanasan dengan aktivitas permainan sebelum ke kegiatan inti (permainan englek)

\section{Kegiatan Inti (50 menit)}

- Memberikan penjelasan tentang permainan dalam kegiatan inti

- Guru membagi dua kelompok n.

- Guru melakukan pendampingan dengan mengkoreksi setiap siswa gerakan siswa yang kurang baik.

- Mengarahkan siswa agar siswa tidak kebingungan tentang apa yang harus mereka lakukan

a) Pembukaan

1) Menanyakan kepada siswa tentang bagian yang merasa sulit.

2) Memberikan solusi kepada siswa tentang kesulitan

b) Analisis

1) Menjelaskan dan memberikan contoh tentang awalan

2) Menjelaskan dan memberikan contoh tentang tolakan

3) Menjelaskan dan memberikan contoh tentang melayang 
4) Menjelaskan dan memberikan contoh tentang mendarat

c) Latihan

1) Latihan tahap awalan

(a) Lompat berturut-turut melewati rintangan

(b) Latihan lompat kijang dengan langkah panjang

(c) Latihan lari sprint

2) Latihan tahap tolakan

(a) Melompat dengan satu kaki yang terkuat

(b) Melompat berturut-turut dengan satu kaki melompati kardus

(c) Menolak pada papan tolakan dari jarak pendek

3) Latihan tahap melayang

(a) Melentingkan badan kerah depan dengan melompat

(b) Menyundul bola yang ada di depan dengan awalan lari

4) Latihan tahap mendarat

(a) Melompat berturut-turut melompati kardus dengan ke 2 kaki rapat

(b) Mendarat dalam lingkaran dengan kaki rapat dengan awalan lari

d) Sistesis

1) Siswa diberi tugas gerak untuk melakukan teknik lompat jauh gaya menggantung secara keseluruhan

2) Memberikan umpan balik kepada siswa

3) Memberikan motivasi kepada siswa

4) Menberikan koreksi secara individu atau klasikal

Kegiatan Penutup (20 menit)

- Mengumpulkan siswa, menjelaskan kembali tentang kegiatan yang telah dilakukan guru menanyakan kepada siswa tentang pemahaman siswa tentang materi lompat jauh gaya menggantung.

- Mengkoreksi pembelajaran yang telah dilakukan oleh siswa

- Guru melakukan penilaian hasil belajar siswa dengan melihat siswa melakukan teknik lompat jauh gaya menggantung.

- Melakukan penenangan terhadap siswa

- Berdo'a dan membubarkan siswa kembali ke kelas

- Membereskan peralatan

\section{Observasi}

Hasil tindakan II siklus I menggambarkan peningkatan pada semua aspek dalam proses pembelajaran lompat jauh gaya menggantung dilakukan dengan metode bagian progresif. Pada tahap ini siswa hanya mengulang materi yang diberikan sebelumnya, siswa terlihat lebih aktif dan antusias, cepat dapat menyesuaikan diri dengan materi pembelajaran lompat jauh gaya menggantung. Diperoleh nilai rata-rata tes ketrampilan teknik lompat jauh gaya menggantung yaitu 74,97 mengalami peningkatan 8,22.

\section{Refleksi}

Setelah data terkumpul, didiskusikan bersama kolaborator kemudian direfleksikan sebagai berikut: (1) Ada peningkatan pada pembelajaran siklus II dibandingkan siklus I, baik dilihat dari pengelolaan kelas, maupun proses belajar mengajar menggunakan metode bagian progresif. Penggunaan waktu lebih efektif, karena para siswa telah mendapatkan informasi lebih jelas dari guru, dan telah memperoleh pengalaman dari pembelajaran; (2)
Pada saat guru meminta siswa untuk berpasangan antara siswa laki-laki dan perempuan, siswa masih canggung sehingga guru ikut berperan dalam pembentukan kelompok; (3) Siswa lebih menghargai teman yang kurang mampu melakukan tugas gerak, karena pembelajaran tidak menekankan teknik dasar tetapi pengalaman gerak sehingga siswa merasa mampu melakukan pembelajaran yang diberikan oleh guru; (4) Semangat siswa dan keikutsertaan siswa saat pembelajaran juga meningkat. Siswa selalu ingin mencoba melakukan tugas gerak.

Siklus II Pertemuan ke 2

\section{Perencanaan}

Pada dasarnya perencanaan pembelajaran tindakan dua ini sama dengan perencanaan tindakan satu. Secara umum siswa masih ragu-ragu, masih bingung untuk melakukan pembelajaran yang diberikan sehingga memerlukan dorongan motivasi dari guru, baik dari penguatan ataupun arahan-arahan yang dapat meningkatkan percaya diri anak. 


\section{Pelaksanaan}

Kegiatan yang dilaksanakan berdasarkan perencanaan tindakan yang telah ditetapkan, yaitu melaksanakan pembelajaran sesuai rencana pembelajaran yang telah dibuat. Pembelajaran dilaksanakan hari senin tanggal 23 Juni 2012 mulai pukul 07:00 hingga pukul 08:30 WIB. pada apersepsi lebih difokuskan pada peningkatan motivasi melalui arahanarahan yang jelas tentang segala sesuatu hal yang berkaitan dengan lompat jauh gaya menggantung.

Setelah semua siswa berada di lapangan siswa terlihat lebih kondusif, karena pada pertemuan sebelumnya siswa kurang puas melakukan pembelajaran yang diberikan sehingga siswa terlihat siap untuk melaksanakan pembelajaran pendidikan jasmani pada hari itu. Pada pemanasan guru memberikan permainan hijau-hitam, dalam permainan ini siswa terlihat bersemangat lebih sportif dalam melakukannya dengan tidak melanggar peraturan yang diberikan sehingga permainan tersebut menjadi lebih efektif, komunikasi antarsiswa pun lebih terjalin dengan baik walaupun masih terlihat malumalu. Siswa dibagi menjadi 2 tim yaitu tim hijau dan hitam. Apabila guru menyebut hitam maka kelompok hitam menangkap hijau dan hijau menghindar lari ke belakang sampai batas, begitupun sebaliknya. Siswa yang dapat menangkap lawannya mendapat skor.

Pada kegiatan inti guru memberikan permainan lompat jauh gaya menggantung modifikasi yang diberi nama menyundul bola, kurang bisa ataupun kurang menyukai permainan lompat jauh gaya menggantung menjadi terlihat tidak bersemangat/malas untuk mengikuti pembelajaran yang diberikan tetapi pada pertemuan kali ini siswa yang kurang mampu berusah untuk mencoba dan terus mencoba untuk memberikan partisipasi dalam pembelajaran.

Tabel 6. Rencana Pelaksanaan Pembelajaran IV

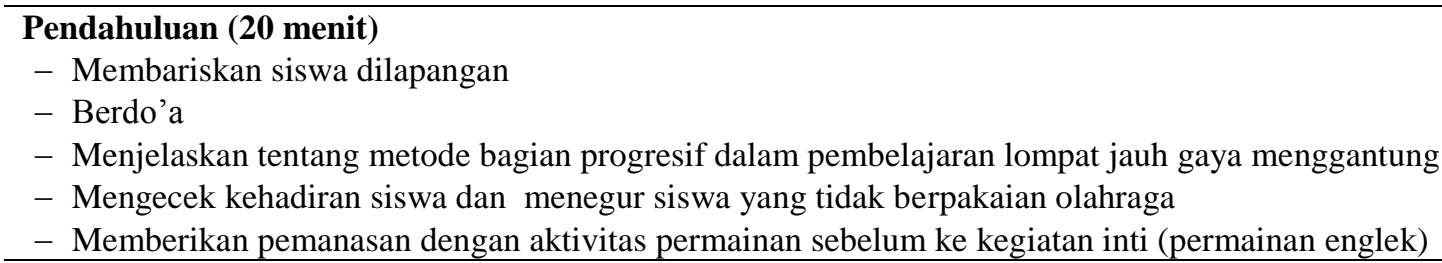

\section{Kegiatan Inti (50 menit)}

- Memberikan penjelasan tentang permainan dalam kegiatan inti

- Guru membagi dua kelompok $\mathrm{n}$.

- Guru melakukan pendampingan dengan mengkoreksi setiap siswa gerakan siswa yang kurang baik.

- Mengarahkan siswa agar siswa tidak kebingungan tentang apa yang harus mereka lakukan

a) Pembukaan

1) Menjelaskan kembali lompat jauh

2) Menjelaskan perbedaan gaya yang ada dalam lompat jauh

b) Analisis

1) Menjelaskan dan memberikan contoh tentang awalan Tujuan: Guna mencapai keepatan maximum yang terkontrol

2) Menjelaskan dan memberikan contoh tentang tolakan

Tujuan: Guna memaximalkan kecepatan vertical dan guna memperke.cil hilangnya kecepatan horizontal

3) Menjelaskan dan memberikan contoh tentang melayang

Tujuan: untuk mempersiapkan suatu pendaratan yang efisien.

4) Menjelaskan dan memberikan contoh tentang mendarat

c) Latihan

Tujuan: Untuk memperkecil hilangnya jarak lompatan

Memberikan latihan gerak teknik lompat jauh gaya menggantung secara berurutan dimulai dari awalan, tolakan, melayang, mendarat

1) Latihan dari awalan, tolakan, melayang, mendarat

2) Dilakuan secara berulang-ulang

d) Sistesis

1) Siswa diberi tugas gerak untuk melakukan teknik lompat jauh gaya menggantung secara keseluruhan

2) Memberikan umpan balik kepada siswa

3) Memberikan motivasi kepada siswa

4) Menberikan koreksi secara individu atau klasikal 


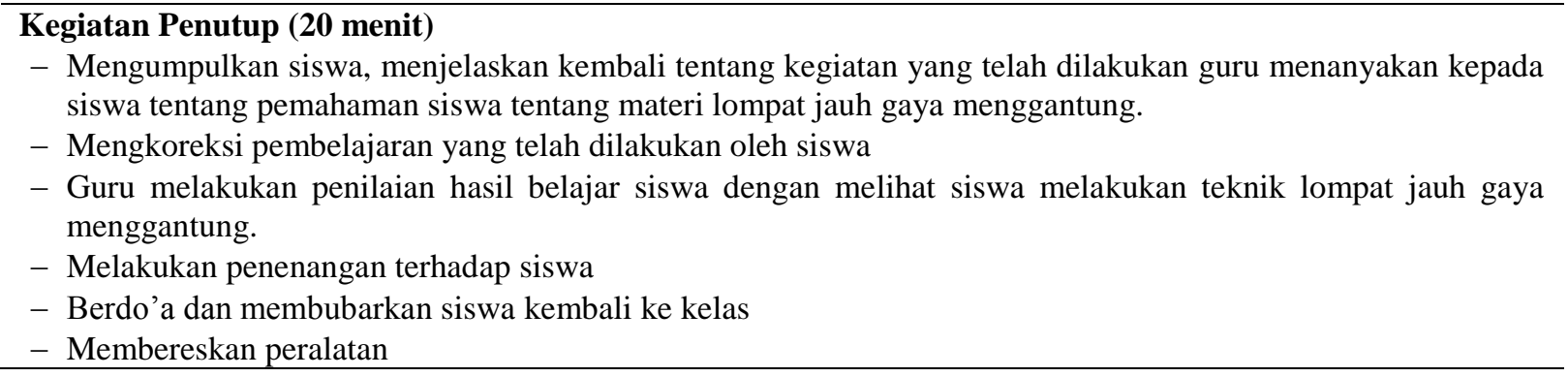

\section{Observasi}

Hasil tindakan II siklus 2 menggambarkan peningkatan pada semua aspek dalam proses pembelajaran lompat jauh gaya menggantung dilakukan dengan metode bagian progresif. Hal ini disebabkan karena upaya guru yang berhasil meningkatkan motivasi siswa dalam pelaksanaan kegiatan pembelajaran sebelumnya yaitu pada siklus I. Pada tahap ini siswa hanya mengulang materi yang diberikan sebelumnya, siswa terlihat lebih aktif dan antusias, siswa cepat dapat menyesuaikan diri dengan materi pembelajaran lompat jauh gaya menggantung.

Diperoleh nilai rata-rata tes keterampilan teknik lompat jauh gaya menggantung yaitu 76,97 mengalami peningkatan 9,21. Setelah dilakukan analisis hasil belajar belum harapan yaitu mencapai kriteria ketuntasan minimal. Siswa yang mencapai batas KKM yaitu nilai 75 ada 6 siswa. Siswa yang mendapat nilai di atas 80 ada 15 siswa dan ada juga yang mendapat nilai di atas 90 ada 2 siswa.

Refleksi

Setelah data terkumpul, didiskusikan bersama kolaborator kemudian direfleksikan sebagai berikut: (1) Ada peningkatan pada pembelajaran siklus II dibandingkan siklus I, baik dilihat dari pengelolaan kelas, maupun proses belajar mengajar menggunakan metode bagian progresif. Penggunaan waktu lebih efektif, karena para siswa telah mendapatkan informasi lebih jelas dari guru, dan telah memperoleh pengalaman dari pembelajaran; (2) Pada saat guru meminta siswa untuk berpasangan antara siswa laki-laki dan perempuan, siswa masih canggung sehingga guru ikut berperan dalam pembentukan kelompok; (3) Siswa lebih menghargai teman yang kurang mampu melakukan tugas gerak, karena pembelajaran tidak menekankan teknik dasar tetapi pengalaman gerak sehingga siswa merasa mereka mampu melakukan pembelajaran yang diberikan oleh guru; (4) Semangat siswa dan keikutsertaan siswa saat pembelajaran juga meningkat. Selalu ingin mencoba melakukan tugas gerak.

\section{Pembahasan Hasil Penelitian}

Perencanaan Pembelajaran

Rumusan tujuan pembelajaran yang tidak diinformasikan secara jelas kepada siswa akan menjadi kendala tercapainya target, seperti yang tejadi disiklus I tindakan I; (a) Pengkoordinasian dalam hal ini pengelolaan waktu harus diperhatikan secara tepat, terkait dengan pengelolaan kelas. Hal ini tampak pada tindakan I siklus I yang mengakibatkan terbuangnya waktu secara percuma; (b) Pembagian kelompok belum terencana dengan baik sehingga mengganggu proses belajar mengajar seperti pada tindakan I siklus I dan tindakan II siklus I; (c) Prosedur perencanaan sangat menentukan pencapaian target keberhasilan pembelajaran.

\section{Pelaksanaan Pembelajaran}

Kegiatan yang dilaksanakan berdasarkan perencanaan tindakan yang telah ditetapkan, yaitu melaksanakan pembelajaran sesuai rencana pembelajaran yang telah dibuat. Pembelajaran dilaksanakan hari senin tanggal 23 Juni 2012 mulai pukul 07:00 hingga pukul 08:30 WIB. pada apersepsi lebih difokuskan pada peningkatan motivasi melalui arahanarahan yang jelas tentang segala sesuatu hal yang berkaitan dengan lompat jauh gaya menggantung.

Setelah semua siswa berada di lapangan siswa terlihat lebih kondusif, karena pada pertemuan sebelumnya siswa kurang puas melakukan pembelajaran yang diberikan sehingga siswa terlihat siap untuk melaksanakan pembelajaran pendidikan jasmani pada hari itu. Pada pemanasan guru memberikan permainan hijau-hitam, dalam permainan ini siswa terlihat bersemangat lebih sportif dalam melakukannya dengan tidak melanggar peraturan yang diberikan sehingga permainan tersebut menjadi lebih 
efektif, komunikasi antarsiswa pun lebih terjalin dengan baik walaupun masih terlihat malumalu. Pada kegiatan inti guru memberikan permainan lompat jauh gaya menggantung modifikasi yang diberi nama menyundul bola, kurang bisa ataupun kurang menyukai permainan lompat jauh gaya menggantung menjadi terlihat tidak bersemangat/malas untuk mengikuti pembelajaran yang diberikan tetapi pada pertemuan kali ini siswa yang kurang mampu berusah untuk mencoba dan terus mencoba untuk memberikan partisipasi dalam pembelajaran.

\section{Observasi}

Hasil tindakan II siklus I menggambarkan peningkatan pada semua aspek dalam proses pembelajaran lompat jauh gaya menggantung dilakukan dengan metode bagian progresif. Hal ini disebabkan karena upaya guru yang berhasil meningkatkan motivasi siswa dalam pelaksanaan kegiatan pembelajaran sebelumnya yaitu pada siklus I. Pada tahap ini siswa hanya mengulang materi yang diberikan sebelumnya, siswa terlihat lebih aktif dan antusias, siswa cepat dapat menyesuaikan diri dengan materi pembelajaran lompat jauh gaya menggantung.

Penilaian tersebut dilakukan secara individu yang kemudian dihitung dan didapat rata-rata 35 siswa. Diperoleh nilai rata-rata tes ketrampilan teknik lompat jauh gaya menggantung yaitu 76,97 mengalami peningkatan 9,21. Setelah dilakukan analisis hasil belajar belum harapan yaitu mencapai kriteria ketuntasan minimal. Siswa yang mencapai batas KKM yaitu nilai 75 ada 6 siswa. Siswa yang mendapat nilai di atas 80 ada 15 siswa dan ada juga yang mendapat nilai di atas 90 ada 2 siswa.

\section{Refleksi}

Ada peningkatan pada pembelajaran siklus II dibandingkan siklus I, baik dilihat dari pengelolaan kelas, maupun proses belajar mengajar menggunakan metode bagian progresif. Penggunaan waktu lebih efektif, karena para siswa telah mendapatkan informasi lebih jelas dari guru, dan telah memperoleh pengalaman dari pembelajaran.

Pada saat guru meminta siswa untuk berpasangan antara siswa laki-laki dan perempuan, mereka masih canggung sehingga guru ikut berperan dalam pembentukan kelompok.

Siswa lebih mengahargai teman yang kurang mampu melakukan tugas gerak, karena pembelajaran tidak menekankan teknik dasar tetapi pengalaman gerak sehingga siswa merasa mampu melakukan pembelajaran yang diberikan oleh guru.

Semangat siswa dan keikutsertaan siswa saat pembelajaran juga meningkat. Selalu ingin mencoba melakukan tugas gerak.

\section{Diskusi Temuan}

Diskusi temuan dengan kolaborator adalah sebagai berikut penerapan metode bagian progresif seorang guru harus benar-benar menerapkan prosedur metode bagian progresif, pembagian tahapan teknik dasar lompat jauh dari yang sederhana ke gerakan yang komplek.

Penerapan metode bagian progresif dalam pembelajaran lompat jauh gaya menggantung pada siswa kelas X F SMAN 1 Ceper Klaten, semula memang sulit diterapkan dan dicerna oleh siswa. Hal tersebut disebabkan karena metode bagian progresif ini baru didapatkan sehingga siswa terlihat bingung dalam memahami materi pembelajaran yang diberikan. Setelah diberi tindakan, arahan dan evaluasi siswa mulai memahami tugas yang harus dikerjakan.

\section{Kesimpulan dan Saran}

Kesimpulan

Berdasarkan hasil pelaksanaan penelitian tindakan kelas dapat disimpulkan: penerapan metode bagian progresif dapat meningkatkan hasil pembelajaran lompat jauh gaya menggantung di Kelas X F SMAN 1 Ceper Klaten Tahun Ajaran 2011/2012, yang ditunjukkan dalam pembelajaran berjalan efektif, hasil belajar siswa meningkat. Hal ini ditunjukan dari hasil belajar dari siklus 1 pertemuan 1 nilai rata-rata 68,75 . Siklus 1 pertemuan 2 nilai rata-rata 72,75. Siklus 2 pertemuan 1 nilai rata-rata 74,97. Siklus 2 pertemuan 2 nilai ratarata 76,97 .

\section{Saran}

Pelaksanaan metode bagian progresif, sebagai salah satu bagian dari pilar pembelajaran Penjasorkes, khusus dan mata pelajaran lainya perlu terus ditingkatkan mengingat cukup signifikan dampak postitif penerapannya terhadap peningkatan motivasi dan hasil belajar siswa;

Guru-guru penjas harus dapat mengenali dan menggunakan berbagai metode, strategi dan/atau model pembelajaran; sehingga mempunyai banyak pilihan untuk diterapkan sesuai dengan materi dan/atau kompetensi da- 
sar, karakteristik siswa serta ketersediaan sarana dan prasarana.

Selain keterampilan memilih metode pembelajaran Penjasorkes, guru penjas yang profesional juga hendaknya dapat memilih media yang tepat untuk menyampaikan materi pembelajaran. Oleh karena itu, guru penjas juga dituntut memliki kreativitas dan keterampilan memilih media pembelajaran yang tepat.

Pelatihan pengembangan metode dan model pembelajaran perlu diberikan oleh lembaga-lembaga terkait, seperti Direktorat PSMP, Direktor PMPTK, LPMP dan lembaga lain yang memiliki kewenangan untuk itu.

\section{Daftar Pustaka}

Depdiknas. (2007). Standar kompetensi dan kompetensi dasar tingkat SD/MI (Mata Pelajaran Pendidikan Jasmani, Olahraga, dan Kesehatan). Jakarta: Depdiknas.
Depdiknas. (2003). Pedoman khusus pengembangan silabus dan penilaian mata pelajaran pendidikan jasmani. Kurikulum 2004 SMA. Jakarta: Direktorat Pendidikan Menengah Umum.

Kemmis, S. dan Taggart, R. (1988). The action research planner. Deakin : Deakin University.

Sugiyanto. (2007). Metodologi penelitian. Surakarta: UNS Press.

Tim Bina Karya Guru. (2004). Penjasorkes untuk sekolah dasar kelas 5. Jakarta: Erlangga.

Wiriaatmadja, Rochiati. (2005). Metode penelitian tindakan kelas. Bandung: PPS UPI dan Remaja Rosda karya. 